\title{
Myopia and Dazzlement: Visions of Venice in Sergio Pitol
}

\author{
Olivia Vázquez-Medina
}

Wadham College, University of Oxford

\begin{abstract}
This article explores the various meanings constructed around the idea of defective sight in Sergio Pitol's Venetian narrative in El arte de la fuga (1996). I argue that through his playful engagement with the many connotations of vision and the place of Venice in the cultural imagination of the West, Pitol puts forward a multi-layered meditation on literature and writing, which are among his main preoccupations in El arte de la fuga and throughout his oeuvre. I also explore the notion of chiaroscuro in a figurative sense as a central feature of Pitol's poetics. To a lesser extent the article also brings to the discussion other texts by Pitol, namely 'El relato veneciano de Billie Upward' (1981) and El viaje (2000).
\end{abstract}

Keywords: Sergio Pitol, El arte de la fuga, Venice in literature, vision in literature, myopia in literature 
Myopia and Dazzlement: Visions of Venice in Sergio Pitol

The mere use of one's eyes in Venice is happiness enough.

Henry James, 'Venice: An Early Impression’

Among the cities that have long captured the cultural imagination of the West, Venice embodies a unique and alluring mixture of mystery, beauty, decay and sensuality. Unlike other European cities, such as Paris or London, Venice 'is not really ever written from the inside but variously appropriated from without', as Tony Tanner reminds us. ${ }^{1}$ Built between water and land, and historically at the crossroads between East and West, it seems to have inspired an infinite number of 'appreciations, recuperations, and dazzled hallucinations' in art and literature. ${ }^{2}$ An author closely associated with the city, Henry James, opens his 1882 remarks on Venice precisely with a comment about its omnipresence:

It is a great pleasure to write the word; but I am not sure there is not a certain impudence in pretending to add anything to it. Venice has been painted and described many thousands of times, and of all the cities of the world is the easiest to visit without going there. [...] There is nothing new to be said about her certainly, but the old is better than any novelty. It would be a sad day indeed when there should be something new to say. I write these lines with the full consciousness of having no information whatever to offer. I do not pretend to enlighten the reader; I pretend only to give a fillip to his memory; and I hold any writer sufficiently justified who is himself in love with his theme. $^{3}$

Within the context of Latin American literature, no European city rivals Paris in importance; yet Latin American authors have been well aware of the tradition of writing Venice, to which some

\footnotetext{
${ }^{1}$ Tonny Tanner, Venice Desired (Cambridge, MA: Harvard University Press, 1992), 5.

${ }^{2}$ Tanner, Venice Desired, 5.

${ }^{3}$ Henry James, 'Venice', in Italian Hours, Project Gutemberg, August 2004, n.p.; available at <http://www.gutenberg.org/files/6354/6354-h/6354-h.htm\#link2H_4_0002> (accessed 10 September 2017); emphasis added.
} 
have also contributed. Twenty-two years after James, Rubén Darío began his own account with comparable observations on the challenge posed to the writer by this striking city:

Escribir sobre Venecia, insistir sobre Venecia... ¿todavía? Bien se pudiera, para nosotros, sobre todo, con un poco del montón estético ruskiniano, con Molmenti, con los mil de la bibliografía veneciana, hacer, al uso del fácil literaturismo, una labor de pintorescos retazos, como del viejo traje de Arlequín, desecho de los últimos carnavales... No en mis días. Uno podría aparecer de repente que me dijese: 'Eso es de Ruskin', o ‘es de Molmenti'. Os doy mejor lo mío, mis impresiones, mis instantáneas intelectuales, a toda luz, para que todos las comprendan y las vean. ${ }^{4}$

Despite their many differences, the travel chronicles by James and Darío suggest a similar conundrum at the prospect of writing about Venice, a city that represents, then as now, 'the already written as well as the already seen, the already read'. ${ }^{5}$ As O'Neill, Sandy, and Wootton assert, if Venice 'entices artistic responses, it often complicates thoughts about the role of the artist' ${ }^{6}$ If James considers himself 'sufficiently justified' to undertake the task, Darío goes on to declare his seeming defeat ironically: ‘QQué hermoso escenario para veinte años vírgenes y una lira! Yo tengo casi el doble, y sin palma; y el instrumento apolíneo creo que se me quedó en Buenos Aires...? ${ }^{7}$

\footnotetext{
${ }^{4}$ Rubén Darío, 'Venecia', from Tierras solares, in Rubén Darío. Del símbolo a la realidad. Obra selecta, edición conmemorativa (Barcelona: Real Academia Española, Asociación de Academias de la Lengua Española, Alfaguara, 2016), 233-238 (p.233); emphasis added. Although compared to other European cities Venice does not feature prominently in Spanish American literature, Adolfo Bioy Casares, Miguel Angel Asturias, Julio Cortázar and Alejo Carpentier are among the authors who wrote about it in the $20^{\text {th }}$ century.

${ }_{6}^{5}$ Tanner, Venice Desired, 17.

${ }^{6}$ Michael O'Neill, Mark Sandy and Sarah Wootton, 'Introduction', in Venice and the Cultural Imagination: 'This Strange Dream upon the Water', ed. Michael O'Neill, Mark Sandy and Sarah Wootton (London and New York: Routledge, 2016) [1 $1^{\text {st }}$ edition 2012], 1-9 (p. 2).

${ }^{7}$ Darío, 'Venecia', 235. Darío's friend and contemporary Ángel de Estrada starts his own chronicle of Venice in the same vein, but laments that his previous knowledge of the city detracts from the experience: 'Cuanto se diga sobre esta ciudad, es poco. Es un caso, quizás el único, en que la realidad abate a la fantasía. Se siente haberla conocido por cuadros y relatos. Se querría encontrarla saliendo al paso, como una isla ignorada' (Ángel Estrada, El color y la piedra [Buenos Aires: Ángel Estrada y Cía, 1900), 395). Pitol's attitude is the exact opposite, as I explore in this essay.
} 
Their initial disclaimers notwithstanding, both James and Darío feel the urge to write about Venice, profusely in the former's case and for only a handful of pages in the latter's. Their accounts reflect a paradox formulated by O’Neill, Sandy, and Wootton:

[Despite] a deepening sense of anxiety that 'Venice is so saturated with meaning that it no longer signifies', writers and artists will seek what Whistler claimed to have captured in his etchings: 'a Venice in Venice that the others never seem to have perceived'.

Interestingly, both James and Darío, like many before and after them, employ in their chronicles a visual vocabulary not only to render their sensorial, mainly ocular, impressions of Venice, but also to address the intellectual process through which an idea of the city will be communicated to the reader and apprehended by her. They both use language that, in English and Spanish, commonly links vision and cognition, as we notice in the terms highlighted in the above quotations. This is unsurprising, given the long history of vision's privileged status in Western thought, exemplified in Plato's and Aristotle's consideration of sight as 'the noblest of senses', and manifest in the fact that 'most Indo-European terms for mental activity apparently derive from words for vision or the visible'.${ }^{9}$ And yet these terms seem even more significant in narratives of a city that, through its associations with art, light and colour, as well as its own existence as a 'strange dream upon the water' (in Dickens' famous words), seems to invite and invoke a reliance on the visual.

A similar emphasis on the visual is apparent, as early as the $16^{\text {th }}$ century, in one of Venice's first appearances in Hispanic poetry:

$$
\begin{aligned}
& \text { Atónito andando, vagando por ella, } \\
& \text { y en éstasi puesto, y en admiración, } \\
& \text { yo mismo a mí mismo, por contemplación, }
\end{aligned}
$$

\footnotetext{
${ }^{8}$ O’Neill, Sandy, and Wootton, 'Introduction', 9.

${ }^{9}$ Kambaskovic Danjiela and Charles T. Wolfe, 'The Senses in Philosophy and Science: From the Nobility of Sight to the Materialism of Touch', in A Cultural History of the Senses in the Renaissance, ed. Herman Roodenburg (London: Bloomsbury, 2014), 107-125 (pp. 107-108).
} 
ageno, estrañado me vía, de vella. ${ }^{10}$

These lines by Juan del Encina express a meditative attitude that is to be found in myriad subsequent texts: a sort of intellectual and emotional mirroring between city and self, whereby the act of gazing upon Venice is accompanied by the speaker's acute self-awareness as a seeing subject; in this case, the poetic 'yo' literally visualizes himself seeing the city. Already in these lines we find a number of motifs associated with Venice in literature: spatial confusion, dazzlement, rapture, and an attitude of self-reflection on the part of the poetic voice that might result in an epiphany, but that here produces a sense of estrangement. With some variations, these motifs are also present in the Venetian texts by Sergio Pitol explored in this essay.

\section{'Sí, también yo he tenido mi visión'}

Fifty-seven years after Darío, in 1961, Pitol arrived in Venice for the first time. The opening chapter of his book El arte de la fuga (1996), entitled 'Todo está en todas las cosas', recounts that visit. The young Pitol has less than a day to see the city before having to leave the country due to a problem with his visa; getting off the train, however, he realizes that he has lost his glasses, and the narrative is a retrospective account—written in February 1996, in Xalapa—of his blurred vision of Venice. ${ }^{11}$ Focusing on this initial chapter of El arte de la fuga, in this paper I explore the ways in which the motif of defective sight, of not quite seeing Venice, is Pitol's creative response to the challenge articulated by writers such as James and Darío-a response deeply informed by a reflection about his own role as a reader and writer. Through his playful engagement with the many connotations of vision and the place of Venice in the cultural imagination of the West, Pitol puts forward a multi-layered meditation on literature and writing,

\footnotetext{
${ }^{10}$ Enrique de Rivera Fadrique, Marqués de Tarifa, Desde Sevilla a Jerusalén. Con versos de Juan de la Encina y prosa del Primer Marqués de Tarifa, estudio y transcripción Joaquín González Moreno, 5th ed. (Sevilla: Monte de Piedad y Caja de Ahorros de Sevilla, 1974 [1st ed. 1521]), 206.

${ }^{11}$ Although Juan Villoro notes how 'convenient' it is for Pitol to lose his glasses in Venice-thereby introducing some doubt as to how literally we should read the incident-Vila-Matas writes about Pitol's 'legendaria [...] inclinación a perder y luego recuperar sus anteojos.' (Juan Villoro, 'Los anteojos perdidos', in Sergio Pitol. Los territorios del viajero, José Balza et al. [Mexico City: Era, 2000], 93-101 [p.98, 101]; Enrique Vila-Matas, 'Pitol, mi maestro', Sergio Pitol, Centro Virtual Cervantes [1997-2017], n.p.; available at 〈http://cvc.cervantes.es/literatura/escritores/pitol/vila_matas.htm〉 [accessed 10 September 2017]).
} 
which are among his main preoccupations in El arte de la fuga and throughout his oeuvre. Pitol's answer to the question raised by James and Darío - how to write about Venice when everything has already been said - is not only discursive but also performative: he offers the reader a vision of the city that enacts an ars poetica best expressed as a visual metaphor, the chiaroscuro. ${ }^{12}$

In visual arts, chiaroscuro 'is an Italian term which translates as light-dark, and refers to the balance and pattern of light and shade in a painting or drawing'; it is generally considered a salient feature of a work whenever 'the artist is using extreme contrasts of light and shade' ${ }^{13}$ In paintings, the term denotes 'clear tonal contrasts which are often used to suggest the volume and modelling of the subjects depicted'.${ }^{14}$ As will be discussed in this essay, Pitol uses the term in 'Todo está en todas las cosas' to describe his unclear vision of Venice, but he employs it elsewhere to refer to a writing technique where a dimension of 'shade' as uncertainty is foregrounded. In that sense, we can notice a link between the traveller's physical myopia, chiaroscuro as the literal interplay between light and shade in a visual image, and the notions of chiaroscuro and myopia in a metaphorical, figurative sense. From the very first page of 'Todo está', the motif of the lost glasses invites us to adopt a particular way of seeing, or rather, not quite seeing a city of which we are likely to possess a mental image. Pitol's text therefore invites us to question what is meant by seeing and not seeing clearly; from the role of the gaze in travel writing to the links between seeing and knowing, the text engages with the semantics of vision, and ocular imagery is the idiom through which Pitol articulates some of his aesthetic and existential concerns in this opening chapter of El arte de la fuga and elsewhere.

\footnotetext{
${ }^{12}$ In a thoughtful piece on El arte de la fuga, Luis $\mathrm{H}$. Castañeda suggests that a different visual metaphor (the self-portrait) is core to Pitol's project in this book, and central to 'Todo está en todas las cosas' ('Zonas de penumbra, fisuras profundas, oquedades abismales: autobiografía, ensayo y experiencia en $E l$ arte de la fuga de Sergio Pitol', in Revista Iberoamericana, LXXXI: 250 [2015], 183-200 [p.188]).

${ }^{13}$ 'Chiaroscuro-Art Term', Tate, n.p.; available at < http://www.tate.org.uk/art/art-terms/c/chiaroscuro> (accessed 10 September 2017).

${ }_{14}$ 'Chiaroscuro', in Glossary, The National Gallery, 2017, n.p.; available at <https://www.nationalgallery.org.uk/paintings/glossary/chiaroscuro> (accessed 10 September 2017).
} 
In this context, Martin Jay's erudite study of the history of vision in Western thought provides a fruitful conceptual framework to approach Pitol. According to Jay,

The tenacious hold of ocularcentrism over Western culture [...] was abetted by the oscillation among [epistemological] models of speculation, observation, and revelation. When one or another faltered, a third could be invoked as the foundation of a still visually privileged order of knowledge..$^{15}$

The first model refers to 'speculative reason, bathing in the light of clear and distinct ideas mirrored in the mind's eye' (epitomised by the Cartesian cogito); the second corresponds to 'mimetic observation, trusting in the reflected light of objects apparent to the two physiological eyes' (exemplified, for instance, in scientific modes of empirical observation); and the third one is embodied in the idea of 'visionary illumination'. ${ }^{16}$ All three models are evoked in Pitol's text, and understanding vision in these different ways can significantly enrich our appreciation of his writing's many nuances, as I explore in what follows.

\section{The viajero's lost glasses}

As a diplomat, scholar and translator, Pitol spent almost thirty years living outside Mexico in cities such as Beijing, Warsaw, Belgrade, Paris, Rome, Moscow, Budapest, Barcelona, and Prague, and many of his works reflect his travels through these and other geographies. Like other texts by this author, El arte de la fuga blurs generic boundaries and reads as a travel chronicle, a memoir, and a literary essay, as well as containing an element of fiction. ${ }^{17}$ The book

\footnotetext{
${ }^{15}$ Martin Jay, Downcast Eyes. The Denigration of Vision in Twentieth-Century French Thought (Berkeley: University of California Press, 1994), 236.

${ }^{16}$ Jay, Downcast Eyes, 236. This does not imply that the privileging of vision has been homogenous or continuous. As Jonathan Crary reminds us, 'Vision can be privileged at different historical moments in ways that simply are not continuous with one another. Situating subjectivity within a monolithic Western tradition of scopic or specular power effaces and subsumes the singular and incommensurable procedures and regimes through which an observer has been constituted' (Techniques of the Observer. On Vision and Modernity in the Nineteenth Century [Cambridge, MA and London: MIT Press, 1992], 57).

${ }^{17}$ Castañeda explains the close connections between three different selves that converge in the first person in El arte de la fuga: 'un yo viajero, un yo escritor y un yo lector que funcionan como variantes unos de los otros' ('Zonas de penumbra', 187). Although I acknowledge the complexity noted by
} 
comprises three parts-'Memoria', 'Escritura', and 'Lecturas' - each including a number of chapters. Despite this apparent thematic division and the varied topics treated in the different chapters, El arte de la fuga has an internal coherence based upon a central concern: 'una constelación de asuntos vinculados con la literatura y, centralmente, con la reflexión sobre la escritura', as Castañeda notes..$^{18}$ In Masoliver's words,

El arte de la fuga tiene un valor incalculable como iluminador de muchos aspectos de la obra de Pitol [...]: tiene mucho de memorias, de diario, de autobiografía, comparte la reflexión, las ideas estéticas, el ensayo literario o el apunte psicológico, y puede ser divertido, sarcástico, crítico o tierno, escéptico o apasionado. Los registros son infinitos y hay un desarrollo narrativo muy acentuado y una espléndida elaboración de carácter circular tanto en cada uno de los capítulos [...] como en el conjunto del libro, que se abre con una Venecia estéticamente prodigiosa vista a través de los ojos de un miope, y se cierra con la no menos prodigiosa iglesia de chamula [sic], en el estado de Chiapas, vista con la mirada del lúcido vidente. ${ }^{19}$

The circularity present within 'Todo está en todas las cosas' is formal and thematic: the chapter is divided into four sections, with the first 'Sí, también yo he tenido mi visión', and last, 'Todo es todas las cosas', centring on Venice. As other critics have noted, the place of 'Todo está' at the beginning of El arte de la fuga - thus inaugurating Pitol's Trilogía de la memoria, which also comprises El viaje (2001) and El mago de Viena (2005)—highlights its paradigmatic character.

Castañeda, and the various ways in which Pitol's writing can be approached from the point of view of the escrituras del yo, such discussion is beyond the scope of this essay. For the sake of simplicity, I only differentiate between an author-narrator, who enunciates his discourse from a present close to the time of publication of the book, in 1996, and his former self (the viajero, a young Pitol). We have in Pitol's text a 'lucid narrator turning back on a past self steeped in ignorance, confusion, and delusion', and therefore an example of what Dorrit Cohn calls 'dissonant self-narration' predicated on the cognitive distance between the 'narrating' and 'experiencing' selves (Transparent Minds: Narrative Modes for Presenting Consciousness in Fiction [Princeton: Princeton University Press, 1978], 145).

${ }^{18}$ Castañeda, 'Zonas de penumbra', 186.

19 Juan Antonio Masoliver, 'Sergio Pitol', in Fractal 10 (1993), n.p., available at <http://www.mxfractal.org/F10masol.html> (accessed 10 September 2017). 
Given that 'Todo está' can be considered a piece of travel writing, it seems pertinent to note here that the genre has traditionally been largely predicated on the visual as its main cognitive sense (thus representing an instance of Jay's second ocularcentric model of knowledge). According to Patricia Almácegui:

Desde Herodoto, se había transmitido a generaciones de viajeros la pasión por la mirada. Las relaciones de descubrimientos y viajes clásicos se caracterizaron por una economía de la mirada, regulada por la transparencia del discurso, la competencia representativa y la adecuación al objeto descrito. ${ }^{20}$

In her seminal Imperial Eyes: Travel Writing and Transculturation (1992), Mary Louise Pratt has underscored and critiqued the way in which the visual also served as a means of appropriation within the logic of European expansion and imperialism. She uses the term the 'seeing-man' for 'the European male subject of European landscape discourse- he whose imperial eyes passively look out and possess'; an even more imperialistic nuance is perceptible in her category of 'the monarch-of-all-I-survey'. ${ }^{21}$

In contrast, 'Sí, también yo he tenido mi visión' offers the following description of Venice:

Se me escapaban los detalles, se desvanecían los contornos; por todas partes surgían ante mí manchas multicolores, brillos suntuosos, pátinas perfectas. Veía resplandores de oro viejo donde seguramente había descascaramientos en un muro. Todo estaba inmerso

\footnotetext{
${ }^{20}$ Patricia Almácegui, 'El fin del viaje', in Palabras de viaje. Estética y hermenéutica del viaje, coord. Luis Beltrán \& Ignacio Duque García, Discursos I, dir. José Luis Rodríguez García (Bellcaire d'Empordá: Edicions Vitel-la, 2007), 89-99, (pp. 90-91). Peter Hulme and Tim Youngs suggest that, for Francis Bacon, the importance of empirical observation in travel writing from the Renaissance onwards was such that 'it was in effect travel writing which provided the vehicle for the conveyance of the new information which laid the foundations for the scientific and philosophical revolutions of the seventeenth century' (Peter Hulme and Tim Youngs, 'Introduction', in The Cambridge Companion to Travel Writing, ed. Peter Hulme and Tim Youngs [Cambridge: Cambridge University Press, 2002], 1-14 [p. 4]).

${ }^{21}$ Mary Louise Pratt, Imperial Eyes: Travel Writing and Transculturation, $2^{\text {nd }}$ ed. (London: Routledge, 2008 [1 $1^{\text {st }}$ ed. 1992]), 9, 197 and passim. The expression 'monarch of all I survey' first occurs in William Cowper's poem 'The Solitude of Alexander Selkirk' (1782).
} 
en la neblina como en las misteriosas Vedute de [sic] Venezia, coloreadas por Turner. Caminaba entre sombras. Veía y no veía, captaba fragmentos de una realidad mutable; la sensación de estar situado en una franja intermedia entre la luz y las tinieblas se acentuó más y más cuando una fina y trémula llovizna fue creando el claroscuro en el que me movía. ${ }^{22}$

By removing his spectacles, Pitol strips the eye of the traveller of its alleged cognitive advantage. The text is entirely predicated on the visual, but this is not an I/eye that can provide reliable ocular information about its surroundings. As Villoro asserts: 'De entrada, Pitol se descalifica como testigo veraz de los sucesos. No es casual que pierda los anteojos en el más escenográfico de los escenarios. ${ }^{23}$ After all, we should remember, with Masoliver, that Pitol has clearly stated that 'jamás podría ser un escritor de viajes en el sentido clásico de la palabra' ${ }^{24}$ Underscoring an alleged physical failure of the eye's powers of observation, the text asserts its own disinterest for mimetic representation, stressing the young Pitol's liminal position, a 'franja intermedia', with respect to an ungraspable 'realidad mutable'. The viajero finds himself inhabiting a chiaroscuro, embedded in a reality that seems to lose density by suspiciously resembling a representation, a painting by JMW Turner. The epistemological value of the model of observation noted by Jay is here clearly diminished, but the above description takes us to the core of the rich intertextual dimension of this narrative.

\section{Venice palimpsest}

In his reading of 'Todo está en todas las cosas', Castañeda asserts that Pitol's text produces a self-portrait of the 'viajero' that is close to Todorov's 'impressionist traveller' on account of 'el gran valor atribuido a las impresiones visuales, en razón de la preponderancia de la percepción y

\footnotetext{
${ }^{22}$ Sergio Pitol, El arte de la fuga (Mexico City: Era, 1996), 12; emphasis added. All subsequent references are to this edition; abbreviated title and page numbers will be given parenthetically.

${ }^{23}$ Villoro, 'Los anteojos perdidos', 98.

${ }^{24}$ Masoliver, 'Sergio Pitol', n.p.
} 
la sensibilidad, que son dimensiones de lo subjetivo'. ${ }^{25}$ Todorov's impressionist traveller, Castañeda continues,

es un cazador de imágenes, un buscador de sensaciones para quien el viaje representa una aventura de los sentidos que debe quedar documentada en 'esbozos, pintados o escritos' [...], esbozos que comportan una recreación estética del paisaje, marcada por el sello de la propia personalidad, más que por el deseo de rendir una representación mimética de las superficies exteriores. ${ }^{26}$

Although I agree that Pitol's text may be read in this way, my contention in this essay is that the author's playful problematization of mimetic representation in 'Todo está en todas las cosas', through the motif of the lost glasses is, above all, a direct response to, and a way of engaging with, Venice's place in the cultural imagination of the West. In other words, his 'recreación estética del paisaje' suggests that his own 'percepción' and 'sensibilidad' are closely connected with his fascination for Venice as 'the great intertextual chamber of Western literature' and art. ${ }^{27}$ The chiaroscuro that the young Pitol finds himself inhabiting is intoxicating because it brings to life other representations of Venice that he cherishes and admires:

Sí, el color, ese gris preponderante que percibía, con fondos ocres, rojos de Siena, verdes botella y constantes dorados se convertía no sólo en fuente de placer para mis ojos maltrechos, sino que estimulaba la mente, la imaginación y la memoria de modo extraordinario. (El arte, 12; emphasis added)

Throughout El arte de la fuga and the rest of his Trilogía de la memoria, Pitol makes clear that the relationship between reading, writing and travelling is one of interdependence and

\footnotetext{
${ }^{25}$ Castañeda, 'Zonas de penumbra', 189.

${ }^{26}$ Castaneda, 'Zonas de penumbra', 189.

${ }^{27}$ Jason Harding, 'The Myth of Venice in the Decline of Eliot and Pound', in Venice and the Cultural Imagination, ed. O’Neill, Sandy, and Wootton, 141-156 (p.143).
} 
contiguity for him. His 'ceguera en Venecia' ${ }^{28}$ is a trigger to his memory and imagination as a reader of visual and literary texts. Although it opens the section on 'Memoria', 'Todo está en todas las cosas' could equally be said to belong to 'Lecturas' (let us remember that circularity that Masoliver rightly notes in El arte de la fuga).

The earlier mention of Turner is just one instance in a narrative where the intertextual dimension is truly overwhelming. From the first paragraph we have allusions to Death in Venice: ‘¿Moriría en Venecia? [...] ¿Renacería, acaso, en Venecia?’ (El arte, 11). ‘Creí localizar', the author-narrator tells us, the Venetian palaces where artists, writers and composers had lived, including Byron, Wagner, Henry James, Robert Browning, and Arthur Schnitzler (El arte, 13-14). Crucially, Pitol does not merely pepper his text with all these references: the never-ending textual relations to which his writing alludes make up the very substance of what we read. Comparing the young Pitol's own 'visión' with that of Turner is further complicated when one considers how Turner himself 'was well aware of the masters who had painted Italy before him [such as Canaletto], and saw the country in a fundamental sense through their eyes'. ${ }^{29}$ If Turner's vision was also influenced by Byron (as is widely acknowledged), the latter's first impressions of the city are already also intertextual, 'taken from writers from Shakespeare onwards' ${ }^{30}$ For Tanner, it seems

absolutely appropriate that the image of Venice which came to dominate the nineteenthcentury imagination—Ruskin's and thus Turner's—-should be at least grounded in an image (Byron's) which in turn was nourished by a textually based text [Ann Radcliffe's The Mysteries of Udolpho.$^{31}$

\footnotetext{
${ }^{28}$ Sergio Pitol, El viaje (Barcelona: Anagrama, 2000), 9. All subsequent references are to this edition; title and page numbers will be given parenthetically.

${ }^{29}$ Andrew Wilton, 'J.M.W. Turner and the "Floating City", in Venice and the Cultural Imagination, ed. O’Neill, Sandy, and Wootton, $43-58$ (p.45).

${ }^{30}$ O'Neill, Sandy, and Wootton, 'Introduction', 5. See also the chapter by Beatty in this volume.

${ }^{31}$ Tanner claims that Radcliffe had herself 'never been to Venice but had experienced it in the writing of Mrs Piozzi' (Venice Desired, 17).
} 
Among this whirlwind of literary and artistic products, spirals, mirrors and reflections, the material city seems to vanish, to lose solidity, as Pitol's narrative implies: Venice is an infinite text. Indeed, if Byron 'was the harbinger of the cult of Venice as a place of enchantment which naturally belongs to the world of art rather than as an actual polis which belongs to history', ${ }^{2}$ that cult is what Pitol is engaging with in 'Todo está en todas las cosas'.

It is therefore unsurprising that the young Pitol starts his tour of the city in 'Florian, el legendario lugar reseñado por todos los escritores y artistas que alguna vez visitaron Venecia' (El arte, 11-12). His directionless wandering through the city-'Me pierdo después. Sólo sé que caminé al azar durante muchas horas, recorrí innumerables calles y crucé varias veces el gran puente del Rialto' (El arte, 13) - is in itself a literary topos associated with Venice. ${ }^{33}$ Pitol's earlier story, 'El relato veneciano de Billie Upward' (1981), arguably an homage to Venice and the literature it has inspired, contains a number of the commanding 'tropes of Venice', as Doody calls them: the labyrinth, the carnival (in the form of disguise and theatricality), and the gondola. Alice, the protagonist of Billie's story, fulfils the idea that the discovery of Venice carries 'a sexual analogy', and that this discovery 'is likely to be represented not only as disconcerting, but also as mysterious in some way' ${ }^{34}$ Alice's fate eventually actualizes the trope of the death in Venice.

When the author-narrator of 'Todo está' goes on to 'imaginar cuál fue el [palacio] de Juliana Bordereau, la centenaria protagonista que custodia [los] codiciadísimos' Aspern's Papers (El arte, 13), we are reminded of Pitol's great admiration for Henry James. In his essay on this novel, first included in the collection oddly titled Adicción a los ingleses-despite dealing with authors including Henry James, Joseph Conrad and Flann O'Brien-and later included in El mago de Viena, Pitol states that James introduces 'un personaje nuevo' in the

\footnotetext{
${ }^{32}$ Bernard Beatty, 'A "More Beloved Existence": From Shakespeare's "Venice" to Byron's Venice', in Venice and the Cultural Imagination, ed. O'Neill, Sandy, and Wootton, 11-26 (p. 11).

${ }^{33}$ For an analysis of spatial disorientation and Venice as a labyrinth, see Margaret Doody, Tropic of Venice (Philadelphia: Pennsylvania University Press, 2007).

${ }^{34}$ Doody, Tropic of Venice, 262.
} 
literature set in Italy, 'el americano'. ${ }^{35}$ Given that he comments on James's life and works to the extent of making reference to some annotations in the latter's 'cuaderno de notas'—which, incidentally, refer to Byron as an inspiration behind Aspern's Papers (Adicción 63-64) - it is likely that Pitol would have read James's Italian Hours, where some descriptions of Venice employ a strikingly similar visual imagery to that found in 'Todo está en todas las cosas'. Indeed, these pages show a fascination with colour, shadows and gleams that reminds us of Pitol's text:

Sea and sky seem to meet half-way, to blend their tones into a soft iridescence, a lustrous compound of wave and cloud and a hundred nameless local reflections, and then to fling the clear tissue against every object of vision. ${ }^{36}$

Moreover, in James' writing on Venice in Italian Hours, there is often no clear distinction between the city and the art it has inspired, much like we encounter in Pitol. ${ }^{37}$

Pitol's text thus draw attention to the impossibility for the author of offering a mimetic representation of the material city that would be separate from the construct of Venice, the city as it exists in the artistic imagination. Venice as a character in literature is a topic that the author-narrator addresses directly in the fourth subsection of this chapter ('Todo es todas las cosas') discussing a duality that he perceives between 'los puritanos' who have demonized it as a place of corruption, sin and ultimately death-'en algunos, el rechazo coincide con una atracción irresistible, y esa dualidad se transforma en delirio' - and 'los defensores', who see it as an object of pleasure, a site of colour, sensuality, carnival, and eroticism (El arte, 23).

\footnotetext{
${ }^{35}$ Sergio Pitol, Adicción a los ingleses. Vida y obra de diez novelistas (Mexico City: Lectorum, 2002), 57. All subsequent references are to this edition; abbreviated title and page numbers will be given parenthetically.

${ }^{36}$ Henry James, 'Venice: An Early Impression', n.p.

${ }^{37}$ The examples are numerous and can be found throughout 'Venice', 'The Grand Canal', and 'Venice: and Early Impression', in Italian Hours. See, for instance: 'The sea took on a thousand shades, but they were only infinite variations of blue, and those rosy walls I just spoke of began to flush in the thick sunshine. Every patch of colour, every yard of weather-stained stucco, every glimpse of nestling garden or daub of sky above a calle, began to shine and sparkle — began, as the painters say, to "compose".' (James, 'Venice', n.p.)
} 
Without employing the term, Pitol therefore delves into the idea of Venice as a palimpsest: in Thomas' words (apropos Prague), 'a constantly rewritten or revised text in which history and imagination, memory and forgetting have been impossible to disentangle' ${ }^{38}$ As such, Venice 'can perhaps be more aptly compared to a multi-layered manuscript on which numerous writers have left their trace without completely effacing the presence of their predecessors' ${ }^{39}$ The 'manuscript' would be, in this case, one heavily illustrated by painters such as Turner. Through its engagement with the Western tradition of writing Venice and the dense intertextuality that re-actualizes that tradition, 'Todo está en todas las cosas' (as well as 'El relato veneciano de Billie Upward', more fully discussed below) can be read as a further layer in the Venetian palimpsest.

A comparison between Venice and Pitol's other 'invisible city', Prague, seems pertinent here. In the introduction to El viaje, Pitol writes about Prague through the rhetorical device of paralipsis, emphasizing a subject by apparently omitting to mention it or failing to elaborate on it, as Borges masterfully does with the story that he 'might write' in 'Tema del traidor y del héroe' (1944). We are told that Prague has 'disappeared' from Pitol's diary and thus the text we read is based on another text that contains an absence. This absence, however, becomes presence in that Prague does emerge from the first pages of El viaje as if conjured up obliquely and through negation-perhaps unsurprisingly, if we take into account that '[d]e todas las ciencias que en Praga tienen cabida la de más prestigio es la alquimia' (El viaje 14), which should warn us to read between the lines. A central motif in this text is again that of the city as a palimpsest, which on this occasion Pitol does note explicitly: 'me deslizaba a la sombra de amplios muros, hechos y rehechos a través de siglos, como palimpsestos de piedra y de diversos barros que guardaran mensajes' (El viaje 14). The chief intertext here is Magic Prague (1973) —itself a richly intertextual palimpsest — by Angelo Maria Ripellino, where the city is referred

\footnotetext{
${ }^{38}$ Alfred Thomas, Prague Palimpsest: Writing, Memory and the City (Chicago and London: University of Chicago Press, 2010), 2.

${ }^{39}$ Thomas, Prague Palimpsest, 7.
} 
to as an "[a]ncient folio of stone parchments, "city-book" in whose pages there is "still so much to be read, to dream, to understand". ${ }^{40}$ In this second 'city-book', the author-narrator walks on the street at the same level as the great characters from the literature of the region (El viaje 14). Just like Venice, Pitol's Prague is not so much a material place-its intangibility is underscored by its disappearance from the diary-as a layering of previous writings. After all, this introduction to El viaje is as much about Prague as it is about the literature, especially Czech, Russian and Austrian, that the author read whilst he was living there, and which would profoundly influence his own writing. ${ }^{41}$

\section{Knowing is Seeing?}

Going back to 'Todo está en todas las cosas', the fact that the texts and authors to which he alludes are European or North American seems entirely natural for an author like Pitol, known for his vast knowledge of foreign languages and literatures, and the incorporation of myriad literary traditions into his writing. The very fact of writing about cities such as Venice and Prague (and others, such as Moscow or Samarkand) signals Pitol's closeness to a diversity of literatures and his eccentric place with respect to canonical notions of the national. If Paris was the city that generations of Latin American authors wrote in the 19th and 20th centuries, Pitol's dislike of the French capital is widely known. With reference to El arte de la fuga, Oswaldo Zavala has convincingly argued that Pitol transcends the dichotomy between 'criollismo' and 'occidentalismo', cosmopolitism and nationalism:

\footnotetext{
${ }^{40}$ Angelo Maria Ripellino, Magic Prague, trans. David Newton Marinelli, ed. Michael Henry Heim (London: Picador, 1995), 6.

${ }^{41}$ Incidentally, in El viaje Pitol claims to have read 'todo Ripellino', including 'his libros de literatura rusa' during his Prague years (19). On this basis, one could assume that he carried on reading him after this period. This is why, despite its clear musical connotations, it seems unlikely that the title for El arte de la fuga is taken from Bach (Castañeda, 'Zonas de penumbra', 186). Instead, it is probably taken from Ripellino's posthumous L'arte della fuga (1987), which comprises five studies on Russian literature, including one on Pitol's much-admired Gogol.
} 
se trata $[\ldots]$ de transitar horizontalmente dentro de una nueva república intelectual que desmantela las jerarquías culturales y normaliza la condición exógena y supuestamente minoritaria del escritor latinoamericano. ${ }^{42}$

Despite agreeing with Zavala, I wonder if there is a hint of postcolonial anxiety in 'Todo está en todas las cosas'. If we are to take his words literally, the author-narrator claims that, in that first visit to Venice, he was not able to see the empirical reality that he encountered: he was merely corroborating that his 'visión' corresponded to the pre-established images that he already had of the city. This recalls a similar situation in a foundational account of a transatlantic 'discovery': Columbus' letters and travelogue, where, scholars such as Beatriz Pastor have argued, description as such is often subordinated to an attempt to make the new reality fit into the preconceived notions and literary models that would have influenced his geographical ideas. ${ }^{43}$ In Pitol, however, the narration of an experience powerfully influenced by a prior imaginary is not written within the framework of a colonising enterprise. On the contrary, what the narrator reveals is a postcolonial subjectivity: the extent to which his own visual perception of Venice was subordinate to a hegemonic Western imaginary of cultural representation - a certain way in which Venice has been seen, mainly by outsiders. As such, his 'visión' entails both myopia (he cannot see beyond it) and dazzlement (it is both wonderful and blinding): 'Mi miopía de ningún modo atenuó el deslumbramiento' (El arte, 11). Even though it does not mention Columbus's writings, the text indirectly evokes them through the anecdote of a Spanish American subject

\footnotetext{
${ }^{42}$ Oswaldo Zavala, 'La síntesis y su trascendencia: Sergio Pitol, la escritura autobiográfica y el fin del occidentalismo', in RILCE, Revista de Filología Hispánica, 28.1 (2012): 257-272 (p.268). According to Zavala, 'el hombre-voz de Pitol habita una identidad cultural compartida por la comunidad intelectual y en particular por ciudadanos multiculturales que, como él mismo, transitan de una tradición a otra sin la mediación de traducciones, agentes editoriales o diplomáticos, estableciendo diálogos horizontales con interlocutores que reducen su condición de extranjero a una mera circunstancia política' (266).

${ }^{43}$ See Beatriz Pastor, Discurso narrativo de la conquista de América (La Habana: Casa de las Américas, 1983).
} 
not quite 'discovering' a European space, which suggests a chiasmic relationship with the European 'discovery' of the Americas. ${ }^{44}$

Although the author-narrator tells us he experienced intense joy in his 'discovery' of Venice, there are further twists in Pitol's text that strike a somewhat discordant note. Eventually, the viajero arrives at a gallery where some paintings by Hieronymus Bosch are exhibited. Given the layout of the exhibition, the narrator describes what he saw as follows:

Había que ver los cuadros desde una distancia considerable, lo que para mí significó enfrentarme con la oscuridad total. De haber sido entonces menos rudimentarios mis conocimientos sobre arte moderno, hubiese podido comparar algunos de esos cuadros con el famoso Negro sobre negro, de Malevich, o con alguno de los enormes lienzos en negro de Rothko, cuya existencia por supuesto ignoraba. (El arte, 13)

Pitol's characteristic humour is at play here, and we realize the irony in the narrator's retrospective account: while apparently noting his previous ignorance, he invites us to appreciate the absurdity of an erudition where even the physical description of darkness is mediated through art. These lines underscore the temporal and cognitive distance from where the narrator tells the story. Can we assume that he has gained self-awareness of the extent to which his sensorial perception in that first visit to Venice had been framed within dominant discourses? Not only had he been unable to see, he had also been a prisoner of hegemonic vision. Although this translates into ecstatic happiness for his former self, as I will discuss below, there is indeed the growing realization that the whole experience may have been an instance of self-delusion. We had a hint of this earlier on, in the first passage quoted: 'Veía resplandores de oro viejo donde seguramente había descascaramientos en un muro' (El arte, 12;

\footnotetext{
${ }^{44}$ Despite the many and profound differences between these texts, this aspect reminds me of Gabriel García Márquez's short story 'El rastro de tu sangre en la nieve', from Doce cuentos peregrinos (1992). In another instance of a Latin American subject lost in a European city, Billy Sánchez wanders through Paris and falls prey of an optical illusion whereby the Eiffel tower (a transparent emblem of French culture) appears to change place as Billy approaches it, thus failing to serve as a reliable point of orientation.
} 
emphasis added). Through irony, and despite the humour, the text betrays a certain degree of scepticism: 'Esa noche, al subir a mi vagón creía conocer Venecia como la palma de mi mano. ¡Qué iluso pobre diablo!' (El arte, 14).

In its humorous reliance on the author's short-sightedness as its central motif, Pitol's text suggests a form of scepticism similar to that expressed by Nietzsche in Beyond Good and Evil:

Our senses are also hostile and averse to the new; and generally, even in the 'simplest' processes of sensation, the emotions DOMINATE — such as fear, love, hatred, and the passive emotion of indolence. [...] Even in the midst of the most remarkable experiences, we still do just the same; we fabricate the greater part of the experience, and can hardly be made to contemplate any event, EXCEPT as 'inventors' thereof. All this goes to prove that from our fundamental nature and from remote ages we have been-ACCUSTOMED TO LYING. Or, to express it more politely and hypocritically, in short, more pleasantly - one is much more of an artist than one is aware of. ${ }^{45}$

Reflecting on the fundamental role of metaphor in the articulation of abstract thought, Lakoff and Johnson explain how, both in Western philosophy and common language, 'concepts related to knowing are conceptualized in terms of corresponding concepts related to seeing' ${ }^{46}$ They situate the origin of the 'Knowing is Seeing' metaphor in Plato and explain how it plays a fundamental role in Descartes' theory of mind.$^{47}$ Nietzsche, on the other hand, would exemplify those later thinkers who challenged what Jay terms 'the ancient scopic régime' of 'Cartesian perspectivalism'. ${ }^{48}$ With a good dose of humour and scepticism (both well-known Pitolean traits), in 'Todo está en todas las cosas' the author plays with different political and

\footnotetext{
${ }^{45}$ Friedrich Nietzsche, The Project Gutenberg EBook of Beyond Good and Evil, trans. Helen Zimmern, 2013, no. 192.

${ }^{46}$ George Lakoff and Mark Johnson, Philosophy in the Flesh: The Embodied Mind and its Challenge to Western Thought (New York: Basic Books, 1999), 238.

${ }^{47}$ Lakoff and Johnson, Philosophy in the Flesh, 391-393.

${ }^{48}$ Jay, Downcast Eyes, 211 and passim.
} 
philosophical connotations of the assumed contiguity between seeing and knowing. Unlike in Descartes, cognition is definitely embodied in Pitol; the physical failure of the young viajero's eyes then gives rise to a whole range of possible meanings of seeing and not seeing in a figurative sense.

\section{Visionary illumination}

What is the nature of the experience that the subject fabricates in 'Sí, también yo he tenido mi visión'? The word 'artist' — even with the ironic tone of the above quotation - is of crucial importance here, given that his first visit to Venice becomes an aesthetic event for the young Pitol, and the text engages with the city as an aesthetic object in Western art and literature. If the second model of vision mentioned by Jay is rendered problematic in 'Todo está en todas las cosas', what about the other two? Let us explore that of 'visionary illumination', evoked from the title 'Sí, también yo he tenido mi visión':

A medida que la niebla me velaba aún más la visión de palacios, plazas y puentes mi felicidad crecía. Caminé tanto que aún hoy me queda la impresión de que aquel día incorporó una inmensa multitud de días. En la marcha, extasiado, repetía una y otra vez una frase de Berenson: 'El mayor regalo que nos han dado los venecianos es el color'. [...] El milagro se había consumado: había cruzado el umbral, el acerado huevo de Leda comenzaba a romperse y en el fondo de las sepulturas se fundían los contrarios. ¿De dónde me venía esa verba esotérica? [...] Recordé una frase que está al final de Al faro: ‘Sí, también yo he tenido mi visión’ [...]. (El arte, 12-14; emphasis added)

The 'iluso pobre diablo' is overtaken by emotion, as Nietzsche would have it. Like the poetic voice in Juan del Encina's poem quoted earlier, the young Pitol is 'extasiado', his 'felicidad' growing as he wanders through the city feasting on the 'visión velada'. Interestingly, for the author-narrator, the memory of the experience alters the sense of time. If the epistemological value of empirical vision is dismissed in this text, the significance of the event is, however, 
affective and aesthetic. Could it be visionary? Defective vision becomes the vehicle for an experience that, towards the end, does acquire mystical overtones—-swiftly dismissed as 'verba esotérica' here, but later expanded on by the author-narrator in the last subsection of the chapter. Pitol's text thus plays with the idea of sensorial misperception as enabling the artist-seer access to a deeper truth, famously expressed, for example, in Rimbaud's so-called 'Lettres du voyant' (1871): 'Il s'agit d'arriver à l'inconnu par le dérèglement de tous les sens. ${ }^{49}$ As far as the mystical connotations are concerned, the idea of visionary blindness is of course much older, as embodied by Tiresias in Greek mythology and the biblical story of St Paul's conversion - and it may be worth remembering here that the words 'miopía' and 'mística' have a common etymological origin. ${ }^{50}$ By quoting the last line of Virginia Woolf's To the Lighthouse (1927), which brings closure to the story of Lily Briscoe's process of creating and completing a painting, Pitol evokes the idea of a secular, artistic epiphany in its sense of a 'moment of sudden and great revelation and realization', elaborated on by Joyce in A Portrait of the Artist as a Young Man. ${ }^{51}$ Importantly, the 'milagro' mentioned above, paired with the idea of revelation, is expanded on in the final section of 'Todo es todas las cosas', which ends with a long quotation from Pitol's other text set in Venice, 'El relato veneciano de Billie Upward' ${ }^{52}$ For reasons of space, I abridge the passage:

Todos los tiempos son en el fondo un tiempo único. Venecia comprende y está comprendida en todas las ciudades [...]. Cada uno de nosotros es todos los hombres [...].

\footnotetext{
49 Arthur Rimbaud, Arthur, «Lettre à Georges Izambard du 13 mai 1871», n.p.; available at <http://abardel.free.fr/petite_anthologie/lettre_du_voyant_panorama.htm> (accessed 10 September 2017). ${ }^{50} \mathrm{I}$ am grateful to Diana Berruezo Sánchez for bringing this to my attention. According to José Antonio Hernández Guerrero, both 'miopía' and 'mística' - as well as 'misterio' - come from the Greek myein "que indica, sobre todo, el acto de cerrar los ojos, de mantener cerrados los ojos, para defenderse de la claridad': '[e]l místico es un [...] "miope" para los objetos externos y un "vidente" para las realidades profundas' (José Antonio Hernández Guerrero, Las palabras de moda, 2nd ed. [Cádiz: Universidad de Cádiz/Universidad de Murcia, 2006], 299).

${ }^{51}$ I am quoting the second meaning of the term epiphany given by the Oxford English Dictionary online, <https://en.oxforddictionaries.com/definition/epiphany> (accessed 10 September 2017). See Marina Ludwigs, 'Epiphany and Closure in Virginia Woolf's To the Lighthouse', Anthropoetics 20.1 (2014), n.p.; available at <http://anthropoetics.ucla.edu/ap2001/2001ludwigs/> (accessed 10 September 2017).

${ }^{52}$ The story was first published in the collection Nocturno de Bujara (1981) and later included in the novel Juegos florales (1982).
} 
¡Todo es todas las cosas! y sólo Venecia, con su absoluta individualidad, iba a revelarle ese secreto! (El arte, 29)

Finishing 'Todo está' with a passage from his earlier text—and, in this same section, discussing how Venice 'ha sido un escenario frecuente en [su] literatura' (El arte, 28) - Pitol further interweaves a meditation on reading and writing with his narrative of Venice. The implications of the idea of illumination within this cluster are discussed in what follows.

'El relato' opens with a character called Gianni, who is in the process of reading a novella written by another character, Billie Upward, entitled Closeness and Fugue. Through this Chinese box structure we learn not only about Gianni's assessment of Billie's text but also the plot of Closeness and Fugue, which concerns the first visit to Venice of a young woman called Alice.$^{53}$ Echoing the multiplication of readers at various narrative levels that we find in stories such as Borges' 'Tema del traidor y del héroe' (1944), we are told that Alice has been deeply affected ahead of her trip by her reading of a book, which we infer to be Casanova's Homecoming, by Arthur Schnitzler (1918). The old seducer, one of Venice's most famous characters, introduces an aura of sensuality and sexual awakening that punctuates Alice's adventures in Venice throughout one night. In her journey, which is as much of self-discovery as it is about the city, she encounters a series of beautiful and bizarre characters amidst a dreamlike and theatrical atmosphere that evaporates in the morning, before the story (both Billie Upward's and Pitol's) ends with her death. Relevant for our discussion of Pitol's engagement with the idea of visionary illumination centred in Venice is the following passage:

Las ventanas abiertas le permiten a Alice conocer todos los interiores que existen en Venecia, enterarse de todas las tragedias, los caprichos, los goces. 'El mundo se le revela no gradualmente sino de modo simultáneo y total.' ('El relato', 129)

\footnotetext{
${ }^{53}$ Sergio Pitol, 'El relato veneciano de Billie Upward', in El hermano gemelo y otros relatos (Bogotá: Norma, 2004), 111-132. All subsequent references are to this edition; abbreviated title and page numbers will be given parenthetically.
} 
This is a clear reference to Borges's 'El Aleph' (1945), where the totality of the universe is revealed to 'Borges', the narrator, as a simultaneous vision. Earlier on Gianni indeed asserts that 'Billie convierte a Alice en una visitadora de una especie de Aleph circunscrito a Venecia' ('El relato', 127). In this context, we can consider the section from 'El relato' that serves as an ending to 'Todo es todas las cosas' through the Borgesian glasses that Pitol is undoubtedly invoking. ${ }^{54}$

The complexities of 'El Aleph' greatly exceed the space that we can accord it in the present discussion beyond a quick consideration of the story's fundamental object: that of 'una pequeña esfera tornasolada, de casi intolerable fulgor' which contains and renders visible the entirety of the cosmos 'desde todos los puntos del universo'. ${ }^{55}$ Critics have discussed the different traditions of mysticism — Kabbalistic, Buddhist, Islamic and Christian — that are at play in the story. ${ }^{56}$ 'Borges', the character-narrator, is the seer whose 'ojos habían visto ese objeto secreto y conjetural, cuyo nombre usurpan los hombres, pero que ningún hombre ha mirado: el inconcebible universo' ('El Aleph', 194). Thus, in a moment of mystical revelation, 'Borges' is able to apprehend 'the cipher of all the infinite complexity of reality'. ${ }^{57}$ In this fantasy of totalizing vision, therefore, Borges overcomes one of the philosophical problems regarding consciousness that has long haunted Western thought, formulated by Jay as that of a

\footnotetext{
${ }^{54}$ Pitol has referred to his admiration for Borges on many occasions. In El mago de Viena, for instance, he recounts his first reading of a story by the Argentinean master, 'La casa de Asterión', in the following terms: 'Fue, quizás, la más deslumbrante revelación en mi vida de lector' (Sergio Pitol, El mago de Viena [Valencia: Pre-Textos, 2005], 11). Castañeda discusses the Borgesian connotations of some phrases in 'Todo está en todas las cosas', apropos the idea of individual identity as a simulacrum, as suggested by Borges in 'De alguien a nadie' (Otras inquisiciones) (see Castañeda, 'Zonas de penumbra', 190-191). ${ }^{55}$ Jorge Luis Borges, 'El Aleph', in El Aleph (Madrid: Alianza Editorial, 1999 [1st ed. 1949]), 175-201 (p.192). All subsequent references are to this edition; title and page numbers will be given parenthetically. ${ }^{56}$ See, for instance, Jaime Alazraki, Borges and the Kabbalah: and Other Essays on His Fiction and Poetry (Cambridge: Cambridge University Press, 1988), 45-46, 49; Gene Bell-Villada, Borges and His Fiction: A Guide to His Mind and Art, 2nd ed. (Austin: University of Texas Press, 1999), 233-234; and the essay extracts by Thiem, Menocal, Elia and Kodama in Harold Bloom, ed., Jorge Luis Borges, Bloom's Major Short Story Writers (New York: Chelsea House, 1986), 85-86, 87-90, and 91-95 respectively.

${ }^{57}$ Steven Boldy, A Companion to Jorge Luis Borges (Woodbridge: Tamesis, 209), 163.
} 
'metasubject able to totalize the whole and see its totalization' ${ }^{58}$ In 'El Aleph', this is done in the following terms,

[V]i la circulación de mi oscura sangre, vi el engranaje del amor y la modificación de la muerte, vi el Aleph, desde todos los puntos, vi el Aleph en la tierra, y en la tierra otra vez el Aleph, vi mi cara y mis vísceras, vi tu cara, y sentí vértigo y lloré (194).

'Borges' is that ideal metasubject that can be both the seeing consciousness and another element of the totality comprised by the Aleph (as is the reader, assuming it is her and not Beatriz Viterbo who is addressed in 'vi tu cara').

The Aleph represents, therefore, the ultimate ocularcentric fantasy of absolute knowledge. If that is so, what could Pitol's comparison of Venice to the Aleph possibly suggest? Many of the ideas in the lines from 'El relato veneciano' that close off 'Todo está en todas las cosas' (quoted earlier) bring to mind standard Borgesian tropes; for example, notions of eternity and other 'juegos con el tiempo y con lo infinito,,${ }^{59}$ or the illusory nature of identity, through the idea that one man can be any man or even all men. There is also a pantheistic notion evident here and made explicit in the Venetian narrative in El arte de la fuga-'Todo está en todas las cosas' becomes 'Todo es todas las cosas', highlighting an ever closer correspondence of being between all things - which evokes the pantheism that critics have detected in Borges's use of enumeration in 'El Aleph' ${ }^{60}$ Interestingly, vision in 'El Aleph' is predicated on the separation between subject and object (even if the subject is simultaneously part of the totality comprised by the object). However, Venice as an 'especie de Aleph' annuls that separation: both the young Pitol in 'Todo está' and Alice in 'El relato' inhabit this idealized, mystical

\footnotetext{
${ }^{58}$ Jay, Downcast Eyes, 291.

${ }^{59}$ Jorge Luis Borges, 'Borges y yo', in Obras completas 1952-1972, vol. 2 (Buenos Aires: Emecé, 2010 [1st ed. 1974]), 197.

${ }^{60}$ Due to lack of space it is not possible to comment in detail on the long enumerations used by both Borges and Pitol when conveying notions of totality. The anaphoric use of 'vi' that Borges memorably uses in 'El Aleph' is also employed by Pitol in 'Todo está en todas las cosas': 'Vi palacios por docenas, y también iglesias, claustros, puentes. Vi torres, almenas y balcones. Vi ojivas y columnas, vi caballos de bronce y leones de mármol [...]' (El arte, 13).
} 
vision of the city. The vision of Venice reveals a 'secreto' to Alice, and to the author-narrator's past and present selves in 'Todo está': the fact that 'todo es todas las cosas', the secret of being and the universe.

On the one hand, we could understand the comparison of Venice to the Aleph in metaliterary terms: as a 'city-book', as a palimpsest, Venice could be compared to the 'esfera tornasolada, de casi intolerable fulgor' where so much of the Western artistic and literary tradition glimmers and shines. For Pitol, a similar compendium is represented by Prague: 'Praga: observatorio y compendio del universo: Imago mundi absoluto: Praga' (El viaje 14). In this line, the succession of colons and the circularity introduced by the epanalepsis enact syntactically the idea of mirrors, totality and reflections. However, of crucial importance is to note that the visionary revelation of Venice leaves a lingering sense of self-deception in 'Sí, también yo he tenido mi visión', as suggested earlier, and ends with death in 'El relato' (in a clear allusion to Mann, but let us remember that death often follows epiphany in Borges). Such detrimental outcomes also link both texts to the negative consequences of attaining the fantasy of total knowledge in 'El Aleph'.61

In his essay on El arte de la fuga, Castañeda argues that the 'yo autobiográfico' put forward in this book is ultimately brought out textually in the tension between construction and dissemination. The conclusion is that 'el máximo grado de autoconocimiento que el yo puede adquirir es su propio misterio'. ${ }^{62}$ Commenting on a passage from the chapter 'Sesión de hipnosis', where the author-narrator describes yet another 'visión' that results in overall obscurity rather than in any sense of enduring revelation, Castañeda asserts, 'se trata de una

\footnotetext{
${ }^{61}$ As Steven Boldy has pointed out, in 'the final lines, though ['Borges'] describes forgetting as 'tragic', the impression is rather of one blotting out a memory too horrible to bear' (A Companion to Jorge Luis Borges, 156.). Moreover, Boldy (p. 156) notes the isolation and even 'absence of self' at the centre of 'Borges's' vision: 'vi todos los espejos del planeta y ninguno me reflejó' ('El Aleph', 192). The story can therefore be read as ridiculing 'one of our intellectual illusions': 'that greater conscious awareness is always life enhancing', as Shaw suggests (Donald Leslie Shaw, 'Jorge Luis Borges: Ficciones', in Landmarks in Modern Latin American Fiction, ed. Philip Swanson [London: Routledge, 1990], 27-49 [p. 44]).

${ }^{62}$ Castañeda, 'Zonas de penumbra', 198.
} 
epifanía envuelta en tinieblas [...] la visión se presenta como una suerte de ceguera' ${ }^{63}$ A similar conclusion can be reached from our reading of epiphany and illumination in Pitol's Venetian texts; the fact that 'Todo está' ends with a long transcription from 'El relato veneciano' refers us back to the earlier text, but the multi-layered textuality of the short story, its self-aware literariness and intertextuality, takes us in a seemingly infinite spiral. There is something mysterious in Pitol's Venetian epiphanies, something not fully graspable. 'A veces imagino que estoy próximo al Umbral, al mítico jardín donde encontraré que todo está en todo', Pitol tells us in El mago de Viena (270), and indeed the reader shares the feeling that being 'próximo' is just one step removed from being fully there. We can, therefore, only agree with Masoliver that Closeness and Fugue is 'la mejor definición [...] para la escritura de Pitol' ${ }^{64}$ Referring to the often disconcerting effect of Pitol's writing, Juan García Ponce states: 'En ninguna de las obras de Sergio, incluida su Autobiografía, sé con exactitud cuál es el reflejo y la repetición y cuál el original que se refleja y repite. ${ }^{65}$ The same can be argued about 'Todo está en todas las cosas' and 'El relato veneciano de Billie Upward': there seems to be an absence at the centre of the revelation, an enduring sense of ambiguity — a prevalence of shade in the chiaroscuro.

\section{Textual chiaroscuro}

A sense of mystery, absence and ambiguity in El arte de la fuga often surrounds the idea of self, as suggested by Castañeda. 'Todo ser humano lleva un misterio que ignora' (El arte, 25), we read in 'Todo está en todas las cosas', and indeed a continuous thread throughout the chapter is that of individual identity. The two middle subsections of the chapter, upon which I have not touched in this discussion, 'Pasado y presente' and 'Almuerzo en el Bellinghousen', deal, among other themes, with the dynamics of a changing sense of self-perception-a mature Pitol reflects on an autobiography that he wrote as a young man and wrestles with humorous

\footnotetext{
${ }^{63}$ Castañeda, 'Zonas de penumbra', 198.

${ }^{64}$ Masoliver, 'Sergio Pitol', n.p.

${ }^{65}$ Juan García Ponce, 'Sergio Pitol: la escritura como misterio, el misterio de la escritura', in Tiempo cerrado, tiempo abierto. Sergio Pitol ante la crítica, comp. Eduardo Serrato, introd. Alberto Vital (Mexico City: Era-UNAM, 1994), 36-39 (p.38).
} 
situations regarding his own age and ageing - always in a context involving a relationship with writing and literature. In 'Todo es todas las cosas', the author-narrator addresses the topic again, this time as part of his reflection on Venice.

This concern with identity resonates with the self-reflective tone found throughout Pitol's essayistic writing, but may also be read in the context of Venice's specific importance for the author as the city of his 'antepasados' (El arte, 14). Moreover, an introspective attitude sparked by a wondrous Venice could also be thought of as 'trope' of the city (in Doody's idiom) and also recalls the lines by Juan del Encina cited at the beginning of this essay. In this respect, a much-quoted passage from 'Todo es todas las cosas' reads as follows,

Uno, me aventuro, es los libros que ha leído, la pintura que ha visto, la música escuchada y olvidada, las calles recorridas. Uno es su niñez, su familia, unos cuantos amigos, algunos amores, bastantes fastidios. Uno es una suma mermada por infinitas restas. (El arte, 25$)$

Venice represents, in this first chapter of El arte de la fuga, a magnificent summa of the 'libros', 'pintura', 'música' and 'calles' that have defined Pitol; given the mirroring relationship between city and self that we perceive through the text, it is not surprising that the self-portrait of the author emerging from it partakes in the haziness and chiaroscuro of his vision of the city.

As mentioned before, the idea that 'philosophy per se tends to privilege sight' has been predominant throughout Western thought, despite some notable exceptions. ${ }^{66}$ From Plato through to Descartes and beyond, the tradition of the 'metaphysics of light' is an illustrious one. ${ }^{67}$ The concept that for Jay exemplifies the first model of ocularcentrism is that of 'speculative reason, bathing in the light of clear and distinct ideas mirrored in the mind's eye ${ }^{96}$ — embodied, as we stated earlier, in the 'Knowing is Seeing' metaphor, in Lakoff and Johnson's

\footnotetext{
${ }^{66}$ Kambaskovic and Wolfe, 'The Senses in Philosophy and Science', 109. Jay's comprehensive study (1994) engages with the ways in which vision has been 'denigrated' in $20^{\text {th }}$-century French thought.

${ }^{67}$ Kambaskovic and Wolfe, 'The Senses in Philosophy and Science', 109.

${ }^{68}$ Jay, Downcast Eyes, 236.
} 
words. Just as he does with respect to notions of observation and illumination, Pitol employs a visual vocabulary to engage with speculative reason in his account of defective sight in 'Todo está':

La primera vez, repito, vi la ciudad a ciegas, se me aparecía en fragmentos, surgía y desaparecía, me mostraba proporciones incorrectas y colores alterados. El espectáculo fue irreal y maravilloso al mismo tiempo. Con los años he rectificado esa visión, cada vez más portentosa, cada vez más irreal. De algún modo, mi viaje por el mundo, mi vida entera han tenido ese mismo carácter. Con o sin lentes nunca he alcanzado sino vislumbres, aproximaciones, balbuceos en busca de sentido en la delgada zona que se extiende entre la luz y las tinieblas. (El arte, 24)

From the commonplace association between living and travelling, a parallel is established here between the author's physical myopia and his humble 'vislumbres' in an existential sense. Beyond the unpretentiousness and even self-doubt apparent here, one has the impression that Pitol relishes the chiaroscuro of speculative ambiguity, preferring quest and liminality over clear and distinct ideas, and espousing scepticism rather than the false illusion of certainty-or perhaps even an ideal of mystical/myopic knowledge that differs as substantially from rational speculation as it does from mimetic observation. After all, as Vila-Matas states, Pitol's style 'consiste en huir de esas personas tan terribles que están llenas de certezas'. ${ }^{69}$

Pitol's scepticism feeds into the sense of secrecy, ambiguity and mystery that lies at the very core of his poetics:

Mi acercamiento a los fenómenos es parsimoniosamente oblicuo. Existe siempre un misterio al que el narrador se acerca pausada, morosamente, sin que a fin de cuentas logre despejar del todo la incógnita propuesta. En el acercamiento a esa oquedad

\footnotetext{
${ }^{69}$ Enrique Vila-Matas, 'Pitol, mi maestro', n.p. Masoliver also notes Pitol's scepticism and quotes the author's words, 'nada puede darse nunca por seguro o confiable' ('Sergio Pitol', n.p.).
} 
existente en medio del relato, en las vueltas que la palabra da en torno a ella, se realiza la función de mi literatura. (El mago de Viena 47-48)

In García Ponce's words:

El secreto no se nos entrega nunca, es el material mismo del que está hecha la obra, es el que hace indispensable la escritura, es el que, a través de ella, de la escritura, nos muestra la vida como un misterio cuya revelación sólo confirma su calidad de misterio. ${ }^{70}$

For Pitol, one visual metaphor that encapsulates this essential ambiguity is precisely that of the chiaroscuro. In El mago de Viena, he reflects on El arte de la fuga in the following terms: 'En una técnica de claroscuro, los distintos textos se contemplan, potencian y deconstruyen a cada momento, puesto que el propósito final es la relativización de todas las instancias' (47). Indeed, the notion of chiaroscuro seems to represent an aesthetic ideal for him. He employs the term 'claroscuro' when discussing the technique of writers whom he admires, such as Monsiváis and James (El mago de Viena, 118, 134). In an oft quoted passage from the chapter 'Vindicación de la hipnosis', in El arte de la fuga, Pitol states:

Desde siempre, desde el inicio, lo que había hecho era desperdigar una serie de puntos sobre la página en blanco, como si por azar hubieran caído en ella, sin relación visible entre sí; hasta que de pronto alguno comenzaba a extenderse, a dilatarse y a lanzar tentáculos en busca de los otros, y luego los demás seguían su ejemplo: los puntos se convertían en líneas que corrían por el papel para encontrar a sus hermanas, fuera para subordinarlas o servirlas, hasta que aquel conjunto inicial de puntos se transformaba en

\footnotetext{
${ }^{70}$ Juan García Ponce, 'Sergio Pitol: la escritura como misterio', 39. See also Vila-Matas, 'Pitol, mi maestro', n.p.; Jorge Volpi, 'Siete variaciones sobre temas originales de Sergio Pitol', in José Balza et.al., Sergio Pitol, Los territorios del viajero (Mexico City: Era, 2000), 103-113; José Balza, 'Página para Pitol', in Serio Pitol, Los territorios del viajero, 31; Margo Glantz, 'Sergio Pitol: ¿El espejo de Alicia?', in Tiempo cerrado, tiempo abierto, 138-143; and Carmen Boullosa, 'Sergio Pitol: entre la burla y el espejo', in Tiempo cerrado, tiempo abierto, 54-58.
} 
una figura cada vez más compleja, intricada, con oquedades, pliegues, reticencias, desvanecimientos y oscuros fulgores. Eso era mi escritura o, al menos, el ideal de mi escritura. (89, my emphasis)

The striking visual imagery that Pitol employs here to define his ars poetica is profoundly significant. When we realize the extent to which the first chapter of El arte de la fuga draws on a figurative notion of chiaroscuro in the evocation of Venice, we can fully appreciate this text's paradigmatic character. Pitol's writing in this chapter is performative: it enacts the myopia of the author for the reader. We have a blurred representation of Venice, and detailed descriptions of the city are never seen but left in the dark. At times, the vocabulary in 'Todo está' conveys more an idea of sfumato - the 'desvanecimiento' that Pitol mentions above - than of chiaroscuro. ${ }^{71}$ But what is abandoned in either case is the possibility of a comprehensive, clear and distinct vision of Venice. It is instead through the 'oquedades', 'pliegues', 'reticencias', and 'oscuros fulgores' in Pitol's 'visión' that we can discern the profoundly rich intertextual density of his 'city-book'. The author also takes us close to his idea of mystical epiphany but the vision is again hazy, and the illumination does not last. Instead, it is the very 'franja intermedia entre la luz y las tinieblas' (El arte, 12) that constitutes an aesthetic epiphany for Pitol (hence the first section's title, 'Sí, también yo he tenido mi visión'). The profound discovery in that first visit to Venice is not that of the city itself, but that of a way of seeing: the dazzling combinations of light, colour and shade as an aesthetic principle that is textualized into writing. The notion of chiaroscuro, finally, also pertains to a degree of scepticism in a philosophical sense, as constitutive of a self that remains deeply suspicious of his own certainties: not a consciousness 'bathing in the light of clear and distinct ideas', but rather well aware of its own 'zonas de penumbra' (El arte, 121).

\footnotetext{
${ }^{71}$ Both techniques were pioneered by Leonardo Da Vinci, but sfumato refers to "the "smoky" quality which blurs contours so that figures emerge from a dark background by means of gradual tonal modulations without any harsh outlines' ('Sfumato', in Glossary, The National Gallery, 2017, n.p.; available at <https://www.nationalgallery.org.uk/paintings/glossary/sfumato> [accessed 10 September 2017]).
} 
Juan Villoro has beautifully contrasted Pessoa's request for his glasses at the moment of his death, and Goethe's famous Mehr Licht! (More light!), with Pitol's writing, which 'se funda en el principio opuesto: no busca aclarar sino distorsionar lo que mira' ${ }^{72}$ In Villoro's words,

Sergio Pitol escribe en la nublada región de quien perdió adrede sus anteojos; pretende que su originalidad es fruto de su mala vista y cede a sus lectores el placer de descubrir en los simulacros y los espejismos una realidad más genuina que el mundo que le sirvió de estímulo. Sus mapas cambian mientras son leídos, trazando la duradera verdad del fugitivo. ${ }^{73}$

Despite resembling a travel narrative, 'Todo está en todas las cosas' departs from the genre's traditional reliance on ocular cognition, as well as from the common metaphor of 'reading the city'. Instead, through the motif of (not quite) seeing Venice, in the first chapter of El arte de la fuga Pitol presents the reader with intriguing 'vislumbres' and 'aproximaciones' in a superbly rich text where the city and the eye converge to offer a meditation on memory (both personal and cultural), reading and writing-all topics that are central to this book, to the Trilogía de la memoria, and to Pitol's oeuvre in general. The idiom and imagery through which this is done evoke various epistemological, political, mystical, aesthetic and existential connotations of vision. What is involved in seeing? What and when can we see? How is seeing connected with knowledge, memory, imagination and emotion? What is the interplay between vision and subjectivity? Inviting specular relationships with myriad texts, and taking Venice'una especie de Aleph' that comprises them — as the object of his obsession, Pitol explores these questions as they concern that which marvels, entices and blinds. ${ }^{74}$

Olivia Vázquez-Medina

Wadham College, University of Oxford

\footnotetext{
72 Villoro, 'Los anteojos perdidos', 93.

${ }^{73}$ Villoro, 'Los anteojos perdidos', 101.

${ }^{74}$ I am very grateful to María del Pilar Blanco and Robin Fiddian for their feedback on this essay, and to Christopher Pownall, Diana Berruezo Sánchez and Arantza Mayo for their valuable comments on a previous version.
} 